УДК 598.274.1:591.5(571.5)

DOI 10.18101/2542-0623-2019-3-33-36

\title{
НОВЫЕ ВИДЫ КУКУШЕК ЮЖНОГО ПРЕДБАЙКАЛЬЯ
}

\section{Ю. И. Мельников}

\author{
() Мельников Юрий Иванович \\ кандидат биологических наук, \\ Байкальский музей Иркутского научного центра \\ Россия, 664520, Иркутская обл., пос. Листвянка, ул. Академическая, 1 \\ E-mail: yumel48@mail.ru
}

Многолетние исследования фауны птиц Прибайкалья (1964-2019 гг.) позволяют рассмотреть появление новых очень редких видов настоящих кукушек - малой и индийской. Их выселение с исходных южных ареалов, несомненно, было обусловлено современной динамикой климата. Как известно [Мельников, 2016; 2017; 2018], во второй половине XX в. наблюдались массовые выселения из Центральной Азии к северу многих видов околоводных и водоплавающих птиц. Это было связано с сильным иссушением водно-болотных экосистем в результате катастрофических и обширных засух, нередко охватывающих почти весь Китай и Монголию. В начале XXI в. наметилась тенденция к расширению к северу ареалов многих видов млекопитающих и массовых видов степных растений. В это же время стали отмечаться залеты в Прибайкалье типичных степных, лесных и горных видов птиц. Именно в связи с этой тенденцией, вероятнее всего, связано появление здесь малой и индийской кукушек. Малая кукушка впервые была обнаружена в 2001-2002 гг. в дельте р. Селенги и с тех пор здесь не отмечалась.

Однако в мае - июне 2019 г. на Олхинском плато, в бассейне небольшой речки Каймурастый притока р. Правой Олхи, были обнаружены как малая, так и индийская кукушки, что указывает на продолжающееся развитие засух в Центральной Азии и общую тенденциию к продвижению птиц степных, лесных и горных экосистем к северу. Ключевые слова: Южное Предбайкалье; малая и индийская кукушки; потепление климата; выселение к северу.

\section{Для цитирования}

Мельников Ю. И. Новые виды кукушек Южного Предбайкалья // Природа Внутренней Азии. Nature of Inner Asia. 2019. № 3(12). С. 33-36. DOI 10.18101/2542-0623-2019-3-33-36

Фауна кукушек Южного Предбайкалья хорошо известна — здесь широко распространены два вида: кукушка Cuculus canorus и глухая кукушка Cuculus saturates. Последние монографии и крупные обобщающие работы по фауне птиц данного региона не содержат сведений о других видах этой группы птиц [Доржиев, Гулгенов, 2018; Доржиев и др., 2019; Попов, 2019]. В то же время в нескольких публикациях указывается на залет в дельту р. Селенги 4 июня 2001 г. и 3 июня 2002 г. малой кукушки Cuculus poliocephalus Latham, 1790 [Доржиев, 2011; Доржиев и др., 2003; Доржиев, Бадмаева, 2016]. Необходимо отметить, что именно в начале 2000-х гг. мы регистрировали в Юго-Западном Предбайкалье (Олхинское плато) крики неизвестных нам видов кукушек, но отсутствие качественных записей голосов птиц не 
позволило сделать определенных выводов относительно видов, которым они могли принадлежать. После получения доступа к таким записям они были несколько раз прослушаны и сравнены с нашими регистрациями (разумеется, по памяти). В дальнейшем предпринимались специальные попытки обнаружить этих птиц, но всегда неудачно.

Вновь в гнездовой период этот участок Предбайкалья был обследован только в мае - июне 2019 г. На склонах правого притока ключа, впадающего в небольшую речку Каймурастый (левый приток р. Правая Олха), покрытых разнообразным по возрастному составу сосново-березовым лесом, 26 мая 2019 г. нами зарегистрированы крики, которые однозначно принадлежали индийской кукушке Cuculus micropterus Gould, 1838. Это подтверждается специальным прослушиванием голосов разных видов кукушек в аудиозаписи и сравнением их по свежей памяти в течение нескольких дней после наблюдений. Во время полевых работ были зарегистрированы неоднократные крики самки этого вида и частая отдача голоса самцом, перелетающим с места на место. Попытки подойти к ним из-за очень большого количества ветровала были неудачны, но их крики иногда прослушивались с расстояния около 50 м. В этот же день были зарегистрированы, уже в пойме р. Каймурастый, крики еще одного вида, но большое расстояние прослушивания не позволило сделать каких-либо выводов об их принадлежности к конкретному виду.

Повторное обследование этого участка 9 июня 2019 г. позволило вновь прослушать здесь неоднократные крики индийской кукушки. Однако ниже по течению p. Каймурастый в пойме с зарослями нескольких видов ивы зарегистрированы крики самца и самки малой кукушки. Определение не вызывает сомнений, поскольку перед этим были неоднократно прослушаны аудиозаписи с голосами этих видов птиц. В течение дня мы слышали крики этих видов неоднократно, что указывает на их очень высокую активность, что не вызывает удивления - этот период приходится на время массового гнездования большинства видов воробьиных птиц. Как известно, гнездовой период кукушек синхронизирован с размножением воробьиных птиц, что облегчает поиск и подкладку яиц в их гнезда.

Отсутствие сведений о встречах в Южном Предбайкалье этих видов указывает на чрезвычайно редкие случаи их появления здесь. Однако в приграничных районах России известны залеты южных видов кукушек, малоизвестные широкому кругу исследователей. В последней монографии по неворобьиным птицам Монголии указаны залеты индийской кукушки в долину р. Нумрэг (предгорья Большого Хингана) 6 и 8 июня 1995 г. Возможно, дважды отмечена одна и та же особь [Звонов и др., 2016; Gombobaatar et al., 2011]. Географически данная находка находится на стыке государственных границ Восточной Монголии, России и Северо-Восточного Китая. Залет малой кукушки зарегистрирован в Прихубсугулье (долина р. Дэлгэрмурун) в августе 1995 г. [Звонов и др., 2016; Gombobaatar et al., 2011]. Эта находка находится на стыке границ северной Монголии и России. Следовательно, вероятность проникновения данных видов в Прибайкалье является очень высокой, что подтверждается и встречами малой кукушки в дельте р. Селенги [Доржиев, 2011; Доржиев и др., 2003; Доржиев, Бадмаева, 2016].

В данном случае необходимо отметить, что оба этих вида встречаются в Хабаровском крае и Южном Приморье [Иванов, Штегман, 1978; Коблик и др., 2006; Рябицев, 2014], а основной ареал находится в Юго-Восточной Азии, охватывая южные предгорья Тибета, южный и центральный Китай, всю Корею и прилежащие с севера территории и только на востоке заходит на территорию России. При 
этом ареал малой кукушки в России ограничен восточными границами Приморья, а индийская кукушка встречается и по югу Хабаровского края [Иванов, Штегман, 1978; MacKinnon et al., 2000]. В принципе, в Прибайкалье может быть обнаружен еще один вид кукушки, пока не зарегистрированный здесь - ширококрылая кукушка Hierococcyx (fugax) hyperythrus (Gould, 1856), ареал которой перекрывается с ареалом индийской кукушки [Иванов, Штегман, 1978; Коблик и др., 2006; Рябицев, 2014; MacKinnon et al., 2000]. Следовательно, в свете последних данных, показывающих проникновение многих юго-восточных, южных, юго-западных и западных видов птиц в Прибайкалье, учитывая обширный южный ареал этих видов, вполне вероятно их попадание на территорию России с различных направлений [Мельников, 2016; 2017; 2018; Попов, 2019].

Необходимо обратить внимание и на то, что на начало 2000-х гг. приходится выселение многих видов птиц, не связанных с водно-болотными экосистемами [Мельников, 2017; 2018]. Если ранее встречи залетных птиц типичных степей, лесных и горных экосистем были чрезвычайно редки, то сейчас они уже не вызывают удивления [Мельников, 2018; Попов, 2019]. Хорошо наметилась общая тенденция сильного обсыхания южных водно-болотных экосистем, проникновения ряда массовых видов степных растений, птиц и млекопитающих на север и, местами, сдвиги границ степи к северу [Обязов, 2012; Кирилюк и др., 2012; Горошко, Ткачук, 2012; Davydova, Dubynina, 2015]. В свете этих данных понятно и появление новых видов, не связанных с водно-болотными экосистемами, в Прибайкалье, зарегистрированное лишь в последние десятилетия.

\section{Литература}

Горошко О. А., Ткачук Т. Е. Трансграничная сеть экологического мониторинга в Даурии (ТСЭМ) // Проблемы адаптации к изменению климата в бассейнах рек Даурии: экологические и водохозяйственные аспекты: сб. науч. трудов биосферного заповедника “Даурский”. Чита: Экспресс-издательство, 2012. С. 63-73. Вып. 5.

Доржиев Ц. 3. Птицы Байкальской Сибири: систематический состав, характер пребывания и территориальное размещение // Байкал. зоол. журн. 2011. № 1(6). С. 30-54.

Доржиев Ц. З., Мэйдже С., Дашанимаев В. М. Гнездование ходулочника, залет малой кукушки и другие новые сведения о некоторых птицах Байкальского региона // Современные проблемы орнитологии Сибири и Центральной Азии: материалы II Междунар. орнитол. конф. (16-19 мая 2003 г., г. Улан-Удэ, Россия). Улан-Удэ: Изд-во Бурят. гос. ун-та, 2003. Ч. 1. С. $85-89$.

Доржиев Ц. З., Гулгенов А. 3. Птицы степных экосистем Байкальской Сибири. Улан-Удэ: Изд-во Бурят. гос. ун-та, 2018. 208 с.

Доржиев Ц. З., Дурнев Ю. А., Сонина М. В., Елаев Э. Н. Птицы Восточного Саяна. Улан-Удэ: Бурят. гос. ун-та, 2019. 400 с.

Звонов Б. М., Букреев С. А., Болдбаатар Ш. Птицы Монголии. Ч. І. Неворобьиные (NonPasseriformes). М.: Сельскохозяйственные технологии, 2016. 396 с.

Иванов А. И., Штегман Б. К. Краткий определитель птиц СССР. Л.: Наука, 1978. 560 с.

Кирилюк В. Е., Ткачук Т. Е., Кирилюк О. К. Влияние изменений климата на местообитания и биоту в Даурии // Проблемы адаптации к изменению климата в бассейнах рек Даурии: экологические и водохозяйственные аспекты: сб. науч. трудов биосферного заповедника “Даурский”. Чита: Экспресс-издательство, 2012. С. 46-62.

Коблик Е. А., Редькин Я. А., Архипов В. Ю. Список птиц Российской Федерации. М.: Товво науч. изд. КМК, 2006. $-256 \mathrm{c}$.

Мельников Ю. И. Современная фауна птиц котловины озера Байкал и особенности ее формирования // Изв. Иркут. гос. ун-та. Сер. Биология. Экология, 2016. Т. 16. С. $62-83$. 
Мельников Ю. И. Новые виды птиц котловины озера Байкал (вторая половина ХХ - начало XXI столетия) // Природа Внутренней Азии. Nature of Inner Asia, 2017. № 3(4). С. 38-63.

Мельников Ю. И. Новые виды птиц котловины озера Байкал: анализ видовой и экологической структуры // Изв. Иркут. гос. ун-та. Сер. Биология. Экология. 2018. Т. 24. С. 25-48.

Обязов В. А. Изменение климата и гидрологического режима рек и озер в Даурском экорегионе // Проблемы адаптации к изменению климата в бассейнах рек Даурии: экологические и водохозяйственные аспекты: сб. науч. трудов биосферного заповедника “Даурский”. Чита: Экспресс-издательство, 2012. С. 24-45.

Попов В. В. Залетные виды птиц Иркутской области // Природа Внутренней Азии. Nature of Inner Asia, 2019. № 1(10). С. 55-77.

Рябицев В. К. Птицы Сибири: справочник-определитель. М.; Екатеринбург: Кабинетный ученый, 2014. Т. 2. 452 с.

Gombobaatar S., Monks E. M., Seidler R., Sumiya D., Tseveenmyadag N., Bayarkhun S., Baillie J. E. M., Boldbaatar Sh., Uuganbayar Ch. Mongolian Red List of Birds. Regional Red List Series. Birds. London: Zoological Society of London Press; Ulaanbaatar: National of Mongolian Ornithological Society Press, 2011. V. 7. 1036 p.

Davydova N. D., Dubynina S. S. The Dynamics Indicators of the State of North Steppes of Central Asia in Modern Conditions // Ecosystems of Central Asia under Current Conditions of Socio-Economic Development. Ulaanbaatar (Mongolia), 2015. P. 347-351.

MacKinnon J., Phillipps K., He Fen-qi. A Field Guide to the Birds of China. New York: Oxford University Press, 2000. 586 p.

\section{NEW SPECIES OF CUCKOOS IN SOUTHERN CISBAIKALIA}

\section{Yu. I. Melnikov}

Yuriy I. Melnikov

Cand. Sci. (Biol.),

Baikal Museum of Irkutsk Scientific Center

1 Akademicheskaya St., Irkutsk Oblast, 664520 Listvyanka, Russia

E-mail: yumel48@mail.ru

Long-term studies of the bird fauna in Cisbaikalia (1964-2019) have revealed the appearance of new very rare species of Cuculinae - lesser and Indian cuckoos. Their migration from the native southern areas undoubtedly was conditioned by the current climate dynamics. As known [Melnikov, 2016; 2017; 2018], in the second half of the $20^{\text {th }}$ century, it was observed mass migration of many species of semiaquatic birds and Anseriformes from Central Asia to the north. It was associated with the severe draining of wetland ecosystems resulted from catastrophic and extensive droughts, often covering almost all China and Mongolia. At the beginning of the $21^{\text {st }}$ century, there have been a tendency to expansion of the area of many species of mammals and mass species of steppe plants to the north. At the same time, it is observed visitation of typical steppe, forest and mountain bird species to Baikal region. The appearance of lesser and Indian cuckoos here is precisely connected with this trend. The lesser cuckoo was first founded in 2001-2002 in the Selenga river delta and has not been noted here since then. However, in May - June 2019, both lesser and Indian cuckoos were found on the Olkha plateau, in the basin of small river Kaimurastny, a tributary of the river Pravaya Olkha, this reflects a continued development of droughts in Central Asia and a general tendency to migration of the birds of steppe, forest and mountain ecosystems to the north.

Keywords: Southern Cisbaikalia; lesser and Indian cuckoos; climate warming; eviction to the north. 